\title{
GP5 wt Allele
}

National Cancer Institute

\section{Source}

National Cancer Institute. GP5 wt Allele. NCI Thesaurus. Code C126556.

Human GP5 wild-type allele is located in the vicinity of 3q29 and is approximately $4 \mathrm{~kb}$ in length. This allele, which encodes platelet glycoprotein $\mathrm{V}$ protein, plays a role in von Willebrand factor-dependent platelet aggregation. 